\title{
Prognostic Significance of E-cadherin, $\beta$-catenin, c-erbB2, and p53 in Gastric Cancer
}

\author{
위암에서 E-cadherin, $\beta$-catenin, c-erbB-2, 그리고 p53 발현의 예후 인자로서 임상적 유용성
}

'Department of Surgery, ${ }^{2}$ Clinical Pathology, Soonchunhyang University Medicine School

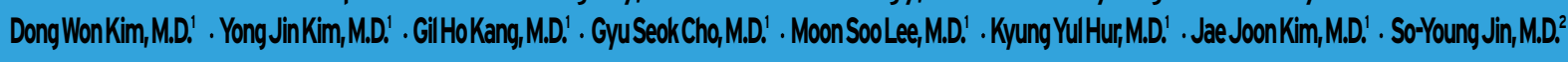

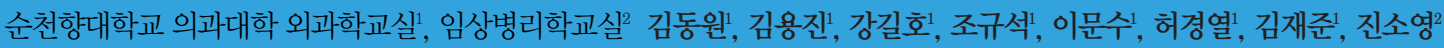

\section{서 론}

전 세계적으로 위암의 발생빈도는 감소추세에 있으나, 국내에 서는 2002 년 현재 전체 암종 중 $20.2 \%$ 의 빈도를 보이고 있으며, 남녀 모두 여전히 증가 추세에 있다. ${ }^{1)}$ 따라서 이들 환자의 치료 효 과를 극대화하고, 부작용을 최소화하며 비용 손실을 막기 위해서 는 정확한 예후 예측이 필수적이라 할 것이다. 현재까지 알려진 가장 강력한 예후인자는, 종양의 침윤 정도, 림프절 전이, 및 원격 전이로 결정되는 UICC TNM병기 이다. 하지만 실제 임상에서는 같은 병기라 할지라도 다양한 예후를 보이고 있어 많은 문제점이 제기 되었고, 여러 차례 개정을 거듭하였다. 이는 UICC TNM병기 체계 이외에 다른 예후인자가 있을 수 있음을 시사하는 것으로, 지난 수 십 년간 눈부신 분자 생물학의 발전에 힘입어 위암에서도 새로운 예후 인자를 밝히고자 하는 많은 노력이 지속되어왔다.

예후 인자를 밝히는데 여러 가지 방법들 즉, DNA 분석, 중합효 소반응, immunoblot, 및 면역조직화학염색 등이 다양하게 적용 되어 왔으며, 이 중 면역조직화학염색은 작은 표본으로 간단하고 빠르게, 그리고 다른 방법들과도 일치된 결과를 보이고 있어 가장 널리 이용되고 있다. 위암의 발생, 성장, 침윤, 및 전이와 관련된 다양한 인자 즉, 종양 유전자, 종양억제 유전자, 성장인자와 그 수 용체, 세포결합 물질, 및 혈관생성인자 등에 대해 많은 연구가 이 루어졌다. 이 중 위암의 예후와 관련성이 보고된 대표적인 경우는 첫째, 종양 유전자로 $\mathrm{K}-\mathrm{sam}, \mathrm{c}-\mathrm{erb} \mathrm{B} 2$, 및 $\mathrm{c}-\mathrm{met}$ 등이 있으 며, $\mathrm{K}-\mathrm{sam}$ 의 경우는 분화암에서 $\mathrm{c}-\mathrm{erb} \mathrm{B} 2$ 의 경우는 미분화암 에서 각각 위암의 예후와 관련이 있는 것으로 잘 알려져 있다. ${ }^{2,3)}$

\section{책임저자 : 김용진}

서울특별시 용산구 한남동 675 순천향대학병원 외과

Tel : 02-709-9479, Fax: 02-795-1687, E-mail : yjkim@hosp.sch.ac.kr

접수일 : 2008년 4월 28일 ; 게재승인일 : 2008년 5월 19일
둘째, 종양억제 유전자로는 $\mathrm{p} 53$ 이 대표적으로 다수의 보고에서 위암과의 관련성이 논의되었나, 예후인자로의 가치는 아직 논란 의 여지가 있다. 그러나 최근의 보고에서는 $\mathrm{p} 53$ 의 비정상적 발현 이 장기적인 환자의 예후에 영향을 미치며, 또한 $\mathrm{p} 53$ 의 발현 정 도가 항암치료에 대한 반응에 영향을 미친다고 보고하여 다시 그 중요성이 대두 되고 있다. ${ }^{4,5)}$ 셋째, 세포결합물질로서 위암과 관련 성이 보고 된 것으로는 $\mathrm{E}$-cadherin, $\beta$-catenin, 및 $\mathrm{CD} 44$ 등 이 있으며, 이 중 $\mathrm{E}$-cadherin의 경우는 다변량 분석에서 독립적 인 예후인자로 보고 되고 있다. ${ }^{6}$ 이외에도 다양한 분자생물학적 예후인자들에 대한 연구결과가 발표 되었으나, 어느 하나 뚜렷한 예후와의 상관관계를 보이지는 못했다.

이에 저자들은 지금까지 비교적 위암의 예후와 관련이 있다고 알려진 $\mathrm{E}$-cadherin, $\beta$-catenin, c-erb B2, 및 p53의 발현 정 도를 면역조직화학염색을 이용하여 평가하고, 다른 예후인자와 관련성을 조사하여 상기 인자들의 예후인자로서 가치를 알고자 본 연구를 고안하였다.

\section{방 법}

\section{1) 환자 및 표본}

순천향대학교 의과대학 외과학 교실에서 위암으로 근치적 위 절제가 이루어진 96예를 대상으로 $\mathrm{E}$-cadherin, $\beta$-catenin, c-erb B2, 및 p53에 대한 면역조직화학염색을 시행하였다. 환자 군의 동질성을 높이고자 단일 술자에 의해 수술이 시행되고, 위암 의 일반적 재발 시기를 고려하여 추적기간을 최소 24 개월 이상으 로 유지하기 위해 2002년에 수술 받은 환자를 대상으로 하였다. 이들 환자의 원발암 장막침윤여부, 림프절 전이 유무, 조직분화 도, Lauren분류 및 종양병기와 각 표지자의 발현 정도를 비교 분 석하였으며, 발현 유무에 따른 생존율을 비교 분석하였다. 재발 확인에 대한 평가는 일차적으로 방사선 결과와 의무기록에 근거 하였고, 전화 추적을 실시하여 생존여부를 확인하였다. 추적 종료 
시점은 2005년 4월 30 일로 하였으며, 중앙 추적기간은 32.1(2.2 42.4)개월이었다. 대상환자의 평균연령은 57.5세였 고, 남자 61 예 그리고 여자는 35 명으로 남녀비는 $1.7: 1$ 이었다. 술 식은 82 명(85.4\%)의 환자에서 하부 위 절제가, 10 명(10.4\%)의 환자에서 위 전 절제가, 그리고 1 명(1.0\%)의 환자에서 상부 위 절 제가 시행되었다. 77 예(79.9\%)의 환자에서 D2 이상의 림프절 절 제술이 시행되었으며, UICC TNM (1997)분류에 따른 수술 후 병기는 IA가 52예(54.2\%), IB가 6예(6.3\%), II가 16예(16.7\%), IIIA가 14 예(14.6\%), IIIB가 5예(5.2\%), 그리고 IV기는 3예 (3.1\%)이었다. 술 후 추적 관찰은 총 96 명의 환자 중 94 명에서 추적이 가능해 추적률은 $98 \%$ 였고, 추적 기간 중 8 예(8.3\%)에서 재발이 확인 되었으며, 이 중 4 예가 이로 인해 사망하였다. 사망 이 확인된 환자는 9 명 $(9.4 \%)$ 이였으며, 이 중 5 명은 다른 동반 질 환 혹은 사고로 사망하였다.

\section{2) 면역조직화학염색 기법 및 결과 판독}

\section{(1) 면역조직화학염색}

파라핀에 포매된 조직을 $4 \mu \mathrm{m}$ 두께로 연속 박절하여 얻은 조직 을 probe on plus 슬라이드 (Fisher, USA)에 부착하여 실험에 사용하였다. 오븐에서 일부 파라핀을 녹인 후 xylene으로 파라핀 을 완전히 제거하였다. 계열 알코올로 함수시킨 후 조직 내 항원 의 재현성을 높이기 위하여 citrate buffer에 넣고 전자 렌지 (Pelco, USA)로 온도를 $100^{\circ} \mathrm{C}$ 로 일정하게 유지시켜 40 분간 끓 여서 잠재된 항원을 노출시켰다. 내인성 과산화효소의 작용을 억 제하기 위하여 $3 \%$ 과산화수소용액에서 10 분간 처리하고 PBS 완 충액으로 세척하였다. 비 특이적인 반응을 방지하기 위하여 $3 \%$ 정상 면양 혈청으로 10 분간 반응시켰다. 슬라이드를 가볍게 턴 후 일차항체를 $4{ }^{\circ} \mathrm{C}$ 냉장고에서 하룻밤동안 반응시켰다. 일차항체로 는 E-cadherin (Zymed, South San Francisco)은 1:50배로 희석하여 사용하였으며 $\beta$-catenin (BD Biosciences, Lexington. KY)은 $1: 100$ 배로 희석하여 사용하였다. p53 (Immunotech, Marceille, France)은 이미 희석된 항체를 사 용하였으며 c-erb B2 (DAKO, California)는 1:200배로 희석 하여 사용하였다. 각 항체를 상온에서 1 시간 반응시켰다. $\mathrm{PBS}$ 완 충액으로 세척한 후 이차항체인 streptavidin biotin complex 를 떨어뜨려 15 분간 상온에서 반응시킨 후 PBS 완충액으로 세척 하였다. 이후 streptavidin peroxidase를 가하여 15 분간 반응 시킨 후 완충액으로 세척하였다. 발색은 amino-ethyl carbazole (AEC)로 3 5분간 반응시킨 후 완충액으로 세척하여 Mayer's hematoxylin으로 대조염색하고 Crystal mount ${ }^{\circledR}$ (Biomeda, CA, USA)로 봉입하였다. 양성 대조표본은 $\mathrm{E}-$ cadherin과 $\beta$-catenin은 정상 위소와상피, p53은 이전 연구에
서 p53 양성으로 확인된 위암조직, c-erb B2는 이전 연구에서 양성으로 확인된 유방암조직을 사용하였으며 음성 대조표본은 일차항체 대신 PBS 완충액으로 대체하여 염색하였다.

\section{(2) 결과판독}

E-cadherin은 암세포의 세포막에 염색도가 감소되거나 소실 되는 것을 관찰하였으며(Fig. $1 \mathrm{~A}$ ), 주 종괴의 소견과 관계없이 가 장 깊이 침윤하는 암종 부위의 염색반응을 기준으로 판독하였다. $\beta$-catenin은 E-cadherin과 마찬가지로 세포막에 염색도가 감소되거나 소실되는 것을 관찰하였으며(Fig. $1 \mathrm{~B}$ ), 세포막에 발 현은 감소 또는 소실되면서 핵이나 세포질에 발현한 비막성 발현 도 항원소실로 간주하였다. c-erb B2는 암종세포의 세포막에 뚜 렷한 적갈색으로 염색되는 경우 양성으로 판독하였다(Fig. 2). $\mathrm{p} 53$ 은 핵에 적갈색으로 염색되는 암세포의 비율이 $5 \%$ 이상일 때 양성으로 판독하였다 (Fig. 3).

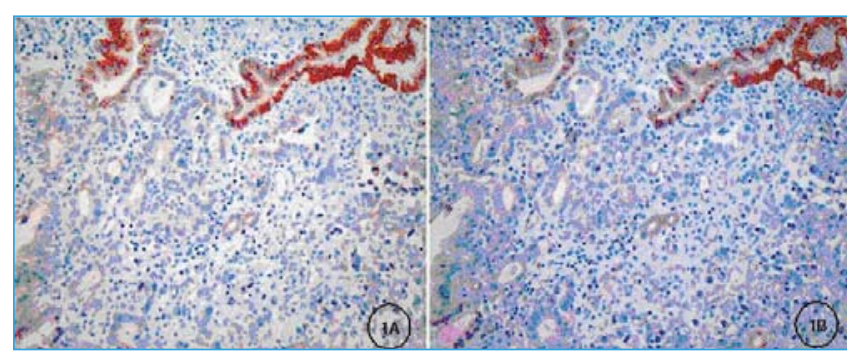

Fig. 1. Immunohistochemistry shows loss of membranous expression for in tumor cells of gastric cancer compared to preserved membranous staining in the normal foveolar epitheliums (upper) (1A; E-cadherin, 1B; $\beta$ catenin, x200)



Fig. 2. Immunohistochemistry exhibit abnormal membranous expression in the tumor cells of gastric cancer (c-erb B2, x200) 


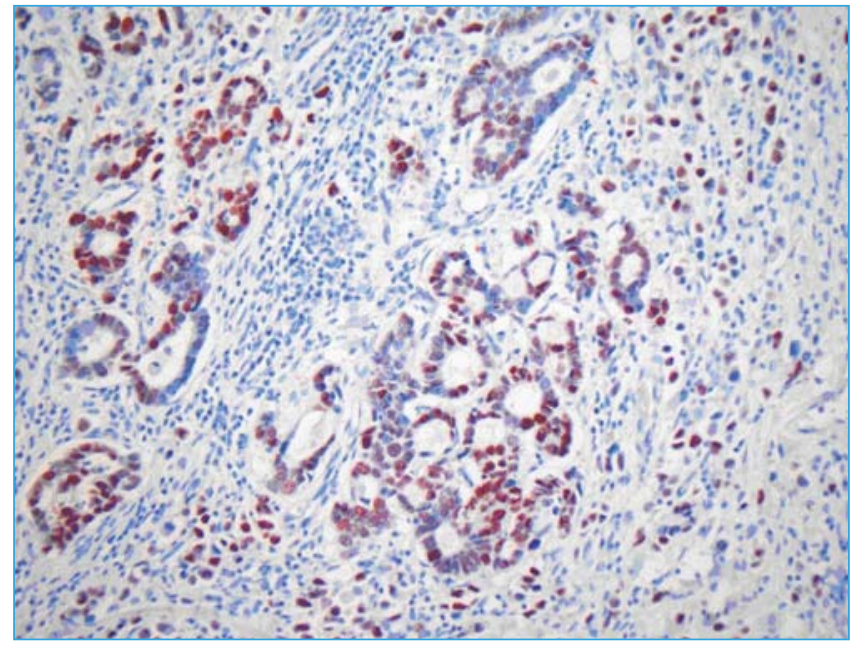

Fig. 3. Immunohistochemistry exhibit diffuse positive staining in the nuclei of tumor cells of gastric cancer $(p 53, x 200)$

\section{(3) 자료분석}

이들에 대한 통계학적인 분석은 SPSS 11.5 for windows을 이용하여, 각각 분자유전학적 표지자의 발현 정도에 따른 임상병 리학적 요인과의 관련성은 Fisher' s exact법을, 생존율은 Kaplan-Meier법과 log-rank법을 이용하여 검정하였으며, 그리고 다변량 분석은 Cox regression analysis를 이용하였다. $\mathrm{p}$ 값이 0.05 이하인 경우를 유의하다 하였다.

\section{결 론 \\ 1) $\mathrm{E}$-cadherin, $\beta$-catenin, c-erb $B 2$, 및 $\mathrm{p} 53$ 의 발현 여부에 따른 예후인자의 비교}

연구대상 96 예 중 60 세 미만인 경우가 49예(51\%)이었으며, 장 막침윤이 있는 경우는 27 예(28.1\%), 림프절 전이가 있는 경우는 35 예(36.5\%)였고, 조직 분화도는 고분화형이 41 예(42.7\%), 저 분화형이 55 예(57.3\%), Lauren분류는 장형이 42 예(43.8\%), 미 만형이 54 예 (56.2\%)였다. E-cadherin의 이상발현은 $76 / 96(79.2 \%), \beta$-catenin의 이상발현은 62/96(64.6\%), cerb B2의 이상발현은 48/96(50\%), 및 p53의 45/96(46.9\%)였 다. $\beta$-catenin, c-erb B2, 및 p53의 경우는 발현 정도에 따라, 나이, 원발암의 침습도, 림프절 전이 유무, 조직형, Lauren 분류 법, 그리고 재발여부와 비교한 결과, 병의 진행 정도 및 재발여부 와 관련성이 없었다. 그러나, E-cadherin의 경우, 장막침윤이 있는 27 예의 환자 중 26 예에서 소실을 보여 장막침윤여부와 유의 한 관련성을 보였다 $(\mathrm{p}<0.05)$. 또한 추적 기간 중 8 예의 환자에서 재발이 확인되었는데 이들 모두는 $\mathrm{E}-\mathrm{cadherin}$ 발현이 정상적으 로 유지되었다(Table 1).

\section{2) 위암 병기별 생존율 및 재발환자의 예후인자 분석}

UICC TNM분류에 따른 병기상 IA와 IB에 해당하는 58예는 추적 종료까지 모두 생존해 있었으며, IV기에 해당하는 3 예도 모

Table 1. Relationship between clinicopathologic parameters and E-cadherin, $\beta$ catenin, c-erbB2, and p53 immunohistochemical expressions in gastric cancer patients(\%)

\begin{tabular}{|c|c|c|c|c|c|c|c|c|c|c|c|c|}
\hline & \multicolumn{3}{|c|}{ E-cadherin } & \multicolumn{3}{|c|}{$\beta^{2}$ catenin } & \multicolumn{3}{|c|}{ c-erb B2 } & \multicolumn{3}{|c|}{ p53 } \\
\hline & abnormal & normal & $p^{*}$ & abnormal & normal & $p$ & abnormal & normal & $p$ & abnormal & normal & $p$ \\
\hline Age(years) & & & 0.45 & & & 1.00 & & & 1.00 & & & 0.54 \\
\hline$<60$ & $37(75.5)$ & $12(24.5)$ & & $32(65.3)$ & $17(34.7)$ & & $24(49.0)$ & $25(51.0)$ & & $21(42.9)$ & $28(57.1)$ & \\
\hline$\geq 60$ & $39(83.0)$ & $8(17.0)$ & & $30(63.8)$ & $34(36.2)$ & & $24(51.1)$ & $23(48.9)$ & & $24(51.1)$ & $23(48.9)$ & \\
\hline Depth of invasion & & & 0.01 & & & 0.64 & & & 1.00 & & & 0.65 \\
\hline $\mathrm{T} 1 / \mathrm{T} 2$ & $50(72.5)$ & $19(27.5)$ & & $46(66.7)$ & $23(33.3)$ & & $35(50.7)$ & $34(49.3)$ & & $31(44.9)$ & $38(55.1)$ & \\
\hline T3/T4 & $26(96.3)$ & $1(3.7)$ & & $16(59.3)$ & $11(40.7)$ & & $13(48.1)$ & $14(51.9)$ & & $14(51.9)$ & $13(48.1)$ & \\
\hline $\begin{array}{l}\text { Lymph node } \\
\text { metastasis }\end{array}$ & & & 0.30 & & & 0.51 & & & 1.00 & & & 1.00 \\
\hline No & $46(75.4)$ & $15(24.6)$ & & $41(67.2)$ & $20(32.8)$ & & $31(50.8)$ & $30(49.2)$ & & $29(47.5)$ & $32(52.5)$ & \\
\hline Yes & 30(85.7) & $5(14.3)$ & & $21(60.0)$ & $14(40.0)$ & & $17(48.6)$ & $18(51.4)$ & & $16(45.7)$ & $19(54.3)$ & \\
\hline Histologic type & & & 0.31 & & & 0.53 & & & 0.41 & & & 0.15 \\
\hline Differentiated & $30(73.2)$ & $11(26.8)$ & & $28(68.3)$ & $13(31.7)$ & & $23(56.1)$ & $18(42.9)$ & & $23(56.1)$ & $18(43.9)$ & \\
\hline Undifferentiated & $46(83.6)$ & $9(16.4)$ & & $34(61.9)$ & $21(38.1)$ & & $25(45.5)$ & $30(54.5)$ & & $22(40.0)$ & $33(60.0)$ & \\
\hline $\begin{array}{l}\text { Lauren } \\
\quad \text { classification }\end{array}$ & & & 0.31 & & & 0.52 & & & 0.30 & & & 1.00 \\
\hline Intestinal & $31(73.8)$ & $11(26.2)$ & & $29(69.0)$ & $13(31.0)$ & & $24(57.1)$ & $18(43.9)$ & & $24(57.1)$ & $18(42.9)$ & \\
\hline Diffuse & $45(83.3)$ & $9(16.7)$ & & $33(61.1)$ & $21(38.9)$ & & $24(44.4)$ & $30(55.6)$ & & $21(38.9)$ & $33(61.1)$ & \\
\hline Recurrence & & & 0.20 & & & 1.00 & & & 1.00 & & & 0.72 \\
\hline No & $68(77.3)$ & 20(22.7) & & $57(64.8)$ & $31(35.2)$ & & $44(50.0)$ & $44(50.0)$ & & $42(47.7)$ & $46(52.3)$ & \\
\hline Yes & $8(100)$ & $0(0.0)$ & & $5(62.5)$ & $3(37.5)$ & & $4(50.0)$ & $4(50.0)$ & & $3(37.5)$ & $5(62.5)$ & \\
\hline
\end{tabular}

*P=P value 
Table 2. Clinicopathologic feature and E-cadherin, $\beta$ catenin, c-erbB2, and p53 immunohistochemical expressions in patients with recurred gastric cancers

\begin{tabular}{|c|c|c|c|c|c|c|c|c|c|c|c|}
\hline Case & Age/Sex & Operation & Differentiation & Lauren classification & Stage & E-cadherin & b-catenin & C-erb B2 & p53 & $\begin{array}{l}\text { Relapse frees survival } \\
\text { (months) }\end{array}$ & Survival status \\
\hline$\# 1$ & $61 / M$ & $\mathrm{DG}^{\wedge}$ & undifferentiated & diffuse & $\|$ & abnormal & normal & abnormal & abnormal & 32 & ALIVE \\
\hline$\# 2$ & $47 / M$ & $D G$ & undifferentiated & diffuse & $\|$ & abnormal & abnormal & normal & normal & 28 & ALIVE \\
\hline$\# 3$ & $62 / M$ & DG & undifferentiated & diffuse & IV & abnormal & abnormal & abnormal & normal & 24 & ALIVE \\
\hline$\# 4$ & $49 / M$ & $D G$ & undifferentiated & diffuse & IV & abnormal & normal & normal & normal & 35 & ALIVE \\
\hline$\# 5$ & $73 / F$ & DG & undifferentiated & diffuse & $111 \mathrm{~B}$ & abnormal & abnormal & normal & normal & 2 & DEAD \\
\hline$\# 6$ & $73 / F$ & $D G$ & differentiated & intestinal & $\|$ & abnormal & abnormal & abnormal & normal & 18 & DEAD \\
\hline$\# 7$ & $70 / F$ & $\mathrm{TG}^{\dagger}$ & undifferentiated & diffuse & ${ }_{I I I} A$ & abnormal & abnormal & normal & abnormal & 2 & DEAD \\
\hline$\# 8$ & $61 / F$ & $D G$ & differentiated & intestinal & $\| \mathrm{A} A$ & abnormal & normal & abnormal & abnormal & 28 & DEAD \\
\hline
\end{tabular}

Table 3. Analysis of prognostic factors in patients with gastric cancers

\begin{tabular}{|c|c|c|c|c|}
\hline Uninariate & & & & \\
\hline & & & & p-value \\
\hline Lymoh node metastasis & & & & 0.0087 \\
\hline Serosa invasion & & & & 0.0277 \\
\hline Undifferentiated histology & & & & 0.7294 \\
\hline Intestinal type & & & & 0.7696 \\
\hline Abnormal E-cadherin expression & & & & 0.3227 \\
\hline Abnormal $\beta$ catenin expression & & & & 0.6591 \\
\hline Abnormal cerb B2 expression & & & & 0.7592 \\
\hline Abnormal & & & & 0.8598 \\
\hline \multirow[t]{2}{*}{ Multivariate:Cox regressional hazard model in stepwise forward fashion } & \multicolumn{4}{|c|}{$95 \% \mathrm{Cl}^{\wedge}$ for realtive risk } \\
\hline & $P$-value & Relative risk & Løwer & Upper \\
\hline Lymph n॰de metastasis & 0.047 & 6.915 & 0.773 & 61.867 \\
\hline
\end{tabular}

${ }^{{ }^{C} \mathrm{Cl}=\text { Confidence interval }}$

두 생존해 있었다. II기 16예 중 1예, IIIA기 14 예 중 2예, 및 IIIB기 5 예 중 1 예가 사망해 각각 $93.8 \%, 85.8 \%, 80.0 \%$ 의 생존 율을 보였으며 전체 대상환자의 생존율은 $95.8 \%$ 였다.

추적 기간 중 모두 8예에서 재발이 확인 되었고, II기가 3예, III기가 3예, 및 IV기가 2예였다. 이들 환자들의 수술 후 재발까 지의 기간은 평균 21 개월(2 35)이었고, 이 중 4 예는 추적 기간 중 사망하였다(Table 2).

\section{3) 예후인자 평가를 위한 단변량 및 다변량 분석}

예후인자 평가를 위한 단변량 분석 결과는 림프절 전이와 장막 침윤만이 유의한 관련성을 보였으며, 그 외에 다른 인자들의 경우 는 통계학적 유의성이 없었다. 또한 다변량 분석을 실시한 결과 림프절 전이만이 비교위험도 6.915 로 유의한 독립적인 예후인자 로 평가 되었다(Table 3).

\section{4) E-cadherin, $\beta$-catenin, c-erb B2, 및 p53의 발현 여부에 따른 질병특이 생존율의 비교}

$\mathrm{E}$-cadherin 정상 발현을 보인 20예의 환자는 모두 재발 없 이 생존해 있었고, E-cadherin 이상 발현을 보인 76예의 환자 에서는 4 예에서 질병관련 사망을 나타냈으나, 각각의 5 년 생존율 은 $100 \%$ 와 $94.7 \%$ 로 이들 두 군간에 통계학적으로 유의한 차이
가 없었다. $(p=0.3227)$ (Fig. 4). 그 외에 $\beta$-catenin, $c$-erb $\mathrm{B} 2$, 및 $\mathrm{p} 53$ 의 경우 역시 생존율과 아무런 관련이 없었다(Fig. 5 7).

\section{고 찰}

조기 위암의 경우는 진단 및 다양한 치료법의 발달로 지난 반세 기를 거치면서 꾸준히 그 예후가 향상되고 있지만, 진행 위암의 경우는 여전히 불량한 예후를 보이고 있다. 이를 극복하고자 지난 수 십 년간 분자 생물학 수준에서 암의 진행 및 전이 기전을 이해 하기 위한 노력을 계속하여 왔으나 뚜렷한 결과를 보이지는 못했 다. 그러나 최근 들어 많은 새로운 기법의 도입으로 다양한 종류 의 분자 생물학적 예후 인자가 등장하고 있으며, 특히 이에 대한 이해는 단순히 예후 판정에 그치는 것이 아니라, 추후 치료계획 및 새로운 약제를 이용한 치료를 통해 예후 증진에 획기적인 전환 이 될 수 있다는 면에서 중요하다고 할 수 있다.

$\mathrm{E}$-cadherin과 $\beta$-catenin은 세포의 형태 유지와 세포간 결합 에 중요한 역할을 담당하며, 암 조직에서 이들의 발현 감소는 암 세포의 침윤과 전이에 관련되는 것으로 알려져 있고, 여러 암 조 직에서 침윤이 심할수록, 원격 전이가 있을수록 $\mathrm{E}$-cadherin과 $\beta$-catenin의 발현이 감소되고 예후가 나쁘다고 알려져 있다. ${ }^{7 \sim 22}$ 본 연구에서도 $\mathrm{E}-$ cadherin의 경우는 장막 침윤 여부와 뚜렷한 


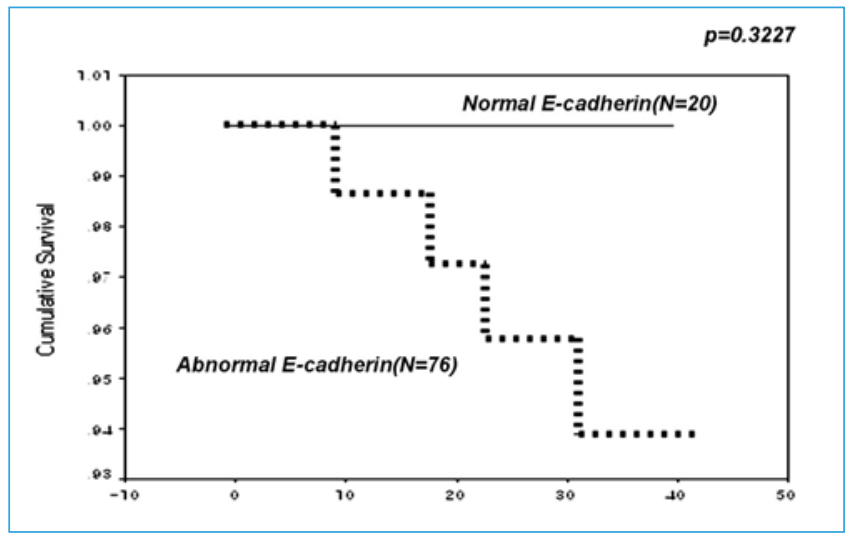

Fig. 4. Kaplan-Meier survival analysis of E-cadherin expression in gastric cancer

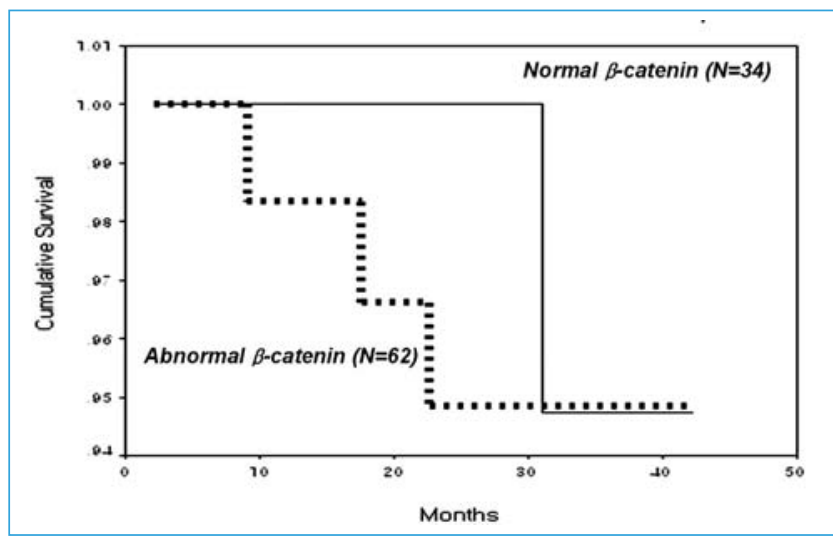

Fig. 5. Kaplan-Meier survival analysis of $\bullet$--catenin expression in gastric cancer

관련성을 보였으나, 재발 여부 및 생존율과는 관련성을 보이지 않 았다. $\beta$-catenin의 경우는 장막 침윤, 림프절 전이, 및 재발여부 등과 아무런 상관관계가 없었으며, 이는 기존의 연구 결과들과 상 반된 결과이다. 특히 Zhou 등흔 163 명의 위암환자를 대상으로 약 $44 \%$ 에서 $\beta$-catenin의 이상 발현을 확인하였고, 이상발현을 보인 경우 림프절 전이와 유의한 관계가 있고, 생존율에도 영향을 미칠 수 있다고 보고하고 있어, 이에 대해서는 추후 더 많은 환자 를 대상으로 추적기간을 충분히 하여 연구할 필요가 있다고 생각 한다.

성장인자 수용체 유전자인 c-erb B2는 1991년에 Yonemura 등 $^{14}$ 이 189 명의 위암환자를 대상으로 $12 \%$ 의 과 발현을 처음 보고 한 이래, 많은 연구에서 동일한 보고를 하고 있으며 국내에서도 $\mathrm{Oh}$ 등 ${ }^{15)}$ 도 $9.2 \%$ 의 과 발현율을 보고하고, 암이 진행될수록 이상 발현이 증가하는 경향이 있다고 보고하였다. 특히 Ross 등흔 든 독 립적인 예후 인자로 유용하다고 보고하였고, Ougolkov 등근 간 전이가 동반된 위암환자 $63 \%(10 / 16)$ 에서 이상발현을 보인 반 면, 대조군인 간 전이가 없는 경우는 $13 \%(5 / 40)$ 에서만 이상 발현

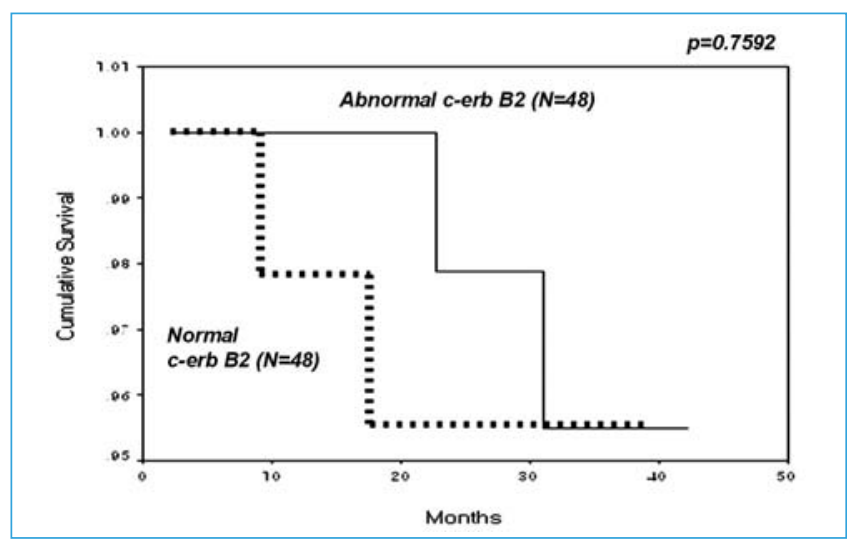

Fig. 6. Kaplan-Meier survival analysis of c-erb B2 expression in gastric cancer

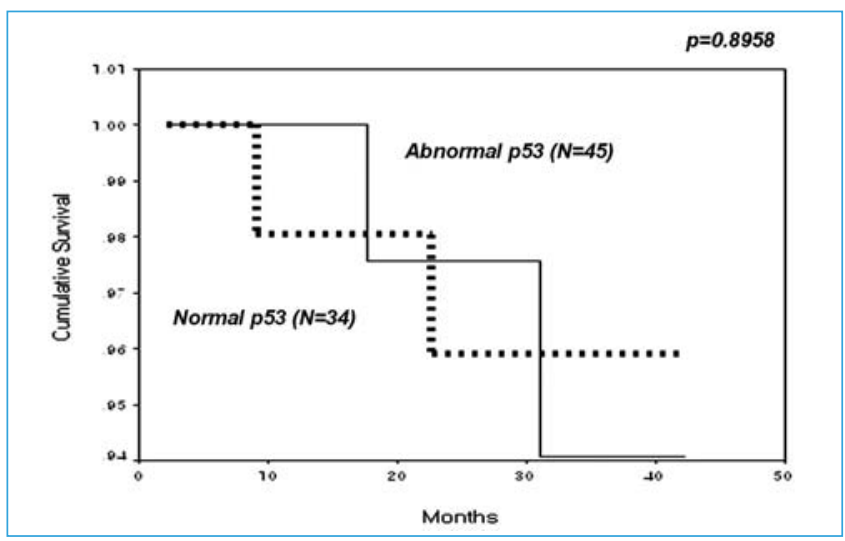

Fig. 7. Kaplan-Meier survival analysis of p53 expression in gastric cancer

을 보여 c-erbB-2 이상발현이 간 전이 예측에 중요한 역할을 할 수 있으며, 동시에 간 전이의 고 위험군이 될 수 있다고 평가하였 다. 그러나 본 연구에서는 c-erbB-2가 암의 진행 정도 및 재발 여부와 관계가 없는 것으로 나타났는데, 그 이유는 연구에 포함된 대부분(77.2\%)의 예가 위암 1 기와 2 기로, 비교적 조기위암에 국한하여 대상 예 선정에 문제가 있었고, $50 \%$ 의 과 발현을 보여 다른 연구 결과에 비해 높은 발현을 보인 것은 면역조직화학기법 혹은 해석상의 문제점이 있을 수 있다고 판단하였다. 비록 본 연 구 결과는 c-erb B2와 위암과 관련성이 떨어지는 것으로 나타났 지만, 최근 분자 표적 치료제의 개발 및 혈청 혹은 소변에서 $c^{-}$ erb B2측정이 가능해짐에 따라 예후 인자로서 그 가능성이 증대 되고 있어, ${ }^{18,19)}$ 지속적이고 적극적인 연구가 필요할 것이다.

종양 억제 유전자인 p53은 세포주기를 조절 함으로써 세포고사 를 유도하여 종양화 과정에서 유전적 변이를 억제 하는 기능을 가 진 인자로 알려져, ${ }^{20)}$ 이미 인체와 관련된 종양인 유방암, 대장암, 난소암, 폐암, 및 식도암에서 그 관련성이 입증되었다. ${ }^{21)}$ 특히 면 역조직화학 염색을 이용하는 데 있어, 돌연변이 p53단백질은 생 
물학적으로 안정되어 있으며, 긴 반감기를 가지고 있어, ${ }^{22)}$ 많은 장 점이 있다. 위암에서 $\mathrm{p} 53$ 의 이상 발현은 $13 \%$ 에서 $54 \%$ 까지 다양 하게 보고하고 있으며, ${ }^{23 ~ 25)}$ 이는 저자들의 결과에서도 $46.9 \%$ 의 이상 발현을 보여 비교적 합당한 소견을 보였다. 예후 인자와 관 련하여 Monig 등 ${ }^{26)}$ 은 133 예의 위암환자를 대상으로 면역조직화 학염색을 시행한 결과 $26.3 \%$ 의 이상발현을 보였으며, 이들 군에 서 불량한 예후를 보여 예후인자로 가치가 있다고 보고하였다. 또 한 Starzynska 등 ${ }^{27)}$ 은 55예의 위암 환자를 대상으로 Martin 등 ${ }^{28)}$ 은 125 예의 위암환자를 대상으로 각각 $47 \%$ 와 $57 \%$ 의 이상 발 현을 보고하였고, 이는 생존율과 유의한 관계를 보여 예후인자로 서 가치가 있음을 시사하였다. 하지만, 일본의 보고 ${ }^{29 ~ 30)}$ 에 의하면 비슷한 이상발현 정도를 보이지만, 예후와는 관련이 없다고 보고 하고 있어 여전히 논란의 여지가 있다. 저자들의 결과 또한 암의 진행 정도 및 재발 여부와 관련이 없는 것으로 미루어 예후 인자 로서 그 가치는 미약한 것으로 판단하였다. 그러나 최근 들어 예 후인자로서 보다는 항암제 반응여부에 $\mathrm{p} 53$ 의 발현 여부가 중요한 영향을 끼친다는 보고하고 있어 그 의미는 새롭게 평가 되어야 할 것이다. ${ }^{5}$

$\mathrm{E}$-cadherin, $\beta$-catenin, 및 c-erb B2의 경우, 다른 보고에 비해 약간 높은 양성률을 보였는데 이는 결과 판독 시, 암 침윤이 가장 심한 종양의 첨단부에서 그 결과를 평가했기 때문이라고 해 석하였으나, c-erb B2의 경우는 심한 편차를 보여 추후 지속적 연구를 위해서는 정도 관리가 필요하다고 판단하였다. 또한 $\beta-$ catenin과 c-erb B2의 경우 위암의 진행 정도와의 상관관계가 다른 보고들과 다른 결과를 보인 것은, 환자의 $70 \%$ 이상이 위암 1 기와 2 기로, 환자 대상 선정의 문제점이 관련이 있을 것으로 판 단하였다. 예후 인자 평가를 위한 단변량 분석 결과 역시 위암 병 기 즉, 장막 침윤 여부와 림프절 전이 여부가 유의한 인자로 평가 되었으며, 다변량 분석을 실시한 결과 림프절 전이가 비교위험도 6.92 로서 의미 있는 예후 인자로 밝혀 졌으나, 하위 신뢰수준이 0.773 으로 나와 그 통계학적 신뢰도가 떨어지는 것으로 나타났는 데 이는 아마도 대상 환자 수 자체가 적고 대상 예의 대부분이 조 기 위암 환자였기 때문으로 판단하였다.

이를 요약하면, $\mathrm{E}$-cadherin의 경우 재발 여부 및 재발 양상을 예측하는 데 도움이 되리라 생각하며, $\beta$-catenin과 c-erb B2의 경우는 비록 저자들의 연구 결과는 위암과 상관관계를 보이지 못 했으나 추후 면역조직화학염색 기법 및 판독의 정도 관리와 대상 예의 확대를 통하여 지속적 연구가 필요할 것이라 생각된다.

\section{결 론}

$\mathrm{E}$-cadherin의 위암조직에서 발현여부는 위암 환자의 가장 강 력한 예후인자인 장막침윤여부와 관련성을 보였으며, 재발 여부
및 생존율에도 영향을 끼칠 수 있는 것으로 나타나 TNM 병기 분 류 이외에 보조적인 예후인자로서 그 가능성을 보였다. 하지만 대 상환자 수가 적고 추적 기간이 짧아 그 결과를 그대로 임상에 반 영하기에는 무리가 있어, 추후 좀 더 많은 환자를 대상으로 충분 한 추적기간을 통하여 연구를 진행해야 그 의의가 올바로 인식 될 수 있을 것이다.

\section{REFERENCES}

1. Central Cancer Registry in Korea. Annual Report of the Central Cancer Registry in Korea. Seoul: Ministry of Health and Welfare, 2002.

2. Yasui W, Oue N, Kuniyasu H, Ito R, Tahara E, Yokozaki H. Molecular diagnosis of gastric cancer: present and future. Gastric Cancer 2001;4:113-121.

3. Werner M, Becker KF, Keller G, Hofler H. Gastric adenocarcinoma: pathomorphology and molecular pathology. J Cancer Res Clin Oncol 2001;127:207-216.

4. Fondevila C, Metges JP, Fuster J, Grau JJ, Palacín A, Castells $A$, et al. p53 and VEGF expression are independent predictors of tumor recurrence and survival following curative resection of gastric cancer. Br J Cancer 2004;90:206-215.

5. Pinto-de-Sousa J, Silva F, David L, Leitao D, Seixas M, Pimenta $A$, et al. Clinicopathological significance and survival influence of p53 protein expression in gastric carcinoma. Histopathology 2004;44:323-331.

6. Shimada $Y$, Yamasaki S, Hashimoto $Y$, Ito T, Kawamura J, Soma $T$, et al. Clinical significance of dysadherin expression in gastric cancer patients. Clin Cancer Res 2004;10:2818-2823.

7. Breen E, Steele G Jr, Mercurio AM. Role of E-cadherin/ $\alpha$-catenin complex in modulating cell-cell and cell-matrix adhesive properties of invasive colon carcinoma cells. Ann Surg Oncol 1995;2:378-385.

8. Oyama T, Kanai Y, Ochiai A, Akimoto S, Oda T, Yanagihara K, et al. A truncated $\beta$ catenin disrupts the interaction between E-caherin and $\alpha$-catenin: a cause of loss of intercellular adhesiveness in human cancer cell lines. Cancer Res 1994;54:6282-6287. 9. Oka H, Shiozaki H, Kobayashi K, Inoue M, Tahara H, Kobayashi $\mathrm{T}$, et al. Expression of E-cadherin cell adhesion molecules in human breast cancer tissues and its relationship to metastasis. Cancer Res 1993;53:1696-1701.

10. Jawhari A, Jordan S, Poole S, Browne P, Pignatelli M, Farthing MJ. Abnormal immunoreactivity of the E-cadherin-catenin complex in gastric carcinoma: relationship with patient survival. Gastroenterology 1997;112:46-54.

11. Kadowaki T, Shiozaki $H$, Inoue $M$, Tamura S, Oka H, Doki Y, et al. Ecadherin and $\alpha$-catenin expression in human esophageal cancer. Cancer Res 1994;54:291-296. 
12. Shino $Y$, Watanabe $A$, Yamada $Y$, Tanase $M$, Yamada $T$, Matsuda $M$, et al. Clinicopathologic evaluation of imunohistochemical E-cadherin expression in human gastric carcinomas. Cancer 1995;76:2193-2201.

13. Zhou YN, Xu CP, Han B, Li M, Qiao L, Fang DC, et al. Expression of E-cadherin and beta-catenin in gastric carcinoma and its correlation with the clinicopathological features and patient survival. World J Gastroenterol 2002;8:987-993.

14. Yonemura $Y$, Ohoyama $S$, Kimura $H$, Kamata $T$, Matsumoto $H$, Yamaguchi $A$, et al. The expression of proliferative-associated nuclear antigen p105 in gastric carcinoma. Cancer 1991;67:2523-2528.

15. Oh ST, Kim JP, Whang TS. The prognostic significance of c-erbB-2 and p53 protein expressions in gastric carcinoma. J Korean Surg Soc 1994;47:634-648.

16. Ross JS, McKenna BJ. The HER-2/neu Oncogene in tumors of the gastrointestinal tract. Cancer Invest 2001;19:554-568.

17. Ougolkov A, Yamashita K, Bilim V, Takahashi Y, Mai M, Minamoto T. Abnormal expression of E-cadherin, beta-catenin, and c-erbB-2 in advanced gastric cancer: its association with liver metastasis. Int J Colorectal Dis 2003;18:160-166.

18. Tsigris C, Karayiannakis AJ, Syrigos KN, Zbar A, Diamantis T, Kalahanis $\mathrm{N}$, et al. Clinical significance of soluble c-erbB-2 levels in the serum and urine of patients with gastric cancer. Anticancer Res 2002;22:3061-3065.

19. Kono K, Takahashi A, Ichihara F, Sugai H, Fujii H, Matsumoto Y. Impaired antibody-dependent cellular cytotoxicity mediated by herceptin in patients with gastric cancer. Cancer Res 2002;62:5813-5817.

20. Milner J, Watson JV. Addition of fresh medium induces cell cycle and conformational changes in p53, a tumour suppressor protein. Oncogene 1990;5:1683-1690.
21. Hollstein $M$, Sidransky D, Vogelstein $B$, Harris CC. p53 mutations in human cancers. Science 1991;253:49-53.

22. Finlay CA, Hinds PW, Tan TH, Eliyahu D, Oren M, Levine AJ. Activating mutations for transformation by $\mathrm{p} 53$ produce a gene product that forms an hsc70-p53 complex with an altered half-life. Mol Cell Biol 1988;8:531-539.

23. Renault $B$, van den Broek $M$, Fodde $R$, Wijnen J, Pellegata NS, Amadori $D$, et al. Base transitions are the most frequent genetic changes at p53 in gastric cancer. Cancer Res 1993;53:2614-2617.

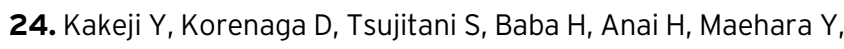
et al. Gastric cancer with p53 overexpression has high potential for metastasising to lymph nodes. Br J Cancer 1993;67:589-593.

25. Seruca R, David L, Holm R, Nesland JM, Fangan BM, Castedo $\mathrm{S}$, et al. p53 mutations in gastric carcinomas. $\mathrm{Br} \mathrm{J}$ Cancer 1992;65:708-710.

26. Mönig SP, Eidt S, Zirbes TK, Stippel D, Baldus SE, Pichlmaier H. p53 expression in gastric cancer: clinicopathological correlation and prognostic significance. Dig Dis Sci 1997;42:2463?2467.

27. Starzynska T, Bromley M, Ghosh A, Stern PL. Prognostic significance of p53 expression in gastric and colorectal carcinoma. Br J Cancer 1992;66:558-562.

28. Martin HM, Filipe MI, Morris RW, Lane DP, Silvestre F. p53 expression and prognosis in gastric carcinoma. Int $\mathrm{J}$ Cancer 1992;50:859-862.

29. Shun CT, Wu MS, Lin JT, Chen SY, Wang HP, Lee WJ, et al. Relationship of p53 and c-erbB-2 expression to histopathological features, Helicobacter pylori infection and prognosis in gastric cancer. Hepatogastroenterology 1997;44:604-609.

30. Sasano H, Date F, Imatani A, Asaki S, Nagura H. Double immunostaining for c-erbB-2 and p53 in human stomach cancer cells. Hum Pathol 1993;24:584-589. 


\title{
Prognostic Significance of E-cadherin, $\beta$-catenin, c-erb B2, and p53 in Gastric Cancer
}

\author{
Department of Surgery', Department of Clinical Pathology, Soonchunhyang University School of Medicine ${ }^{2}$ \\ Dong Won Kim, M.D.' · Yong Jin Kim, M.D.' · Gil Ho Kang, M.D.' · Gyu Seok Cho, M.D.' · Moon Soo Lee, M.D.' . \\ Kyung Yul Hur, M.D.' · Jae Joon Kim, M.D.' · So-Young Jin, M.D. ${ }^{2}$
}

\begin{abstract}
Purpose: Although the TNM stage is the most important prognostic factor for gastric cancer, there is a need for new prognostic factors, because the prognosis varies among patients of the same stage. The aim of this study was to clarify the prognostic significance of E-cadherin, $\beta$-catenin, c-erb B2, and p53 in patients with gastric cancers.

Materials and Methods: Loss of membranous expression of E-cadherin \& $\beta$ catenin, abnormal c-erb B2 membranous expression, and overexpression of p53 were investigated immunohistochemically using 96 cases of paraffin embedded tissue of gastric carcinomas at Soonchunhyang University in 2002. These were correlated with the clinicopathological parameters such as age, depth of invasion, lymph node metastasis, histology, Lauren classification, and survival were analyzed retrospectively. There were 61 males and 35 females (1.7:1) with a mean age of 57.5 years (range:36 73 years).

Results: The percentage of abnormal expression of E-cadherin, $\beta$ catenin, c-erbB-2, and p53 were 76/96 (79.2\%), 62/96 (64.6\%), 48/96 (50\%), and 45/96 (46.9\%), respectively. Abnormal expression of E-cadherin occurred more frequently in serosa-invasive than serosa-noninvasive groups ( $p<0.05$ ). In all cases with preserved expression of E-cadherin, recurrence was not occured regardless of the stage. Abnormal expression of $\beta$ catenin, c-erb B2, and p53 were not related with clnicopathological parameters. The prognosis was associated with lymph node metastasis ( $p=0.0087)$ and serosa invasion $(p=0.0277)$ in an univariate analysis. Lymph node metastasis is an independent prognostic factor in patients with gastric cancers $(p=0.0047)$.

Conclusion: Although this study was performed with small number of cases and shortage of the follow-up time, E-cadherin showed the possibility as one of prognostic factors in gastric cancer.
\end{abstract}

\section{Key Words: Gastric cancer, Prognostic factor, Immunohistochemistry, E-cadherin}

Correspondence : Yong Jin Kim, M.D.

Department of Surgery, Soonchunhyang University School of Medicine, 657 Hannamdong, Yongsangu, Seoul, Korea.

TEL : 82-2-709-9479, FAX:82-2-795-1687, E-Mail : yjkim@hosp.sch.ac.kr

Received : April 28, 2008; Accepted : May 19, 2008 